\title{
Peningkatan Pengetahuan dan Sikap Ibu Hamil Melalui Edukasi Flipchart 1000 HPK
}

Tika Puspita Sari ${ }^{1}$, Betty Yosephin Simanjuntak ${ }^{2 \bowtie}$, Jumiyati Jumiyati $^{3}$

${ }^{1}$ Jurusan Gizi, Poltekkes Kemenkes Bengkulu, Indonesia

${ }^{1}$ Surel/Email patricknmom@yahoo.co.id / 085273286858

\begin{tabular}{l} 
Info Artikel \\
\hline Sejarah Artikel: \\
Diterima : 31 Mei 2020 \\
Disetujui : 12 Juni 2020 \\
Di Publikasi : 1 November \\
2020 \\
\hline
\end{tabular}

Keywords: 1000 HPK, edukasi, pengetahuan, sikap

DOI:

https://doi.org/10.32763/juke.v $13 \mathrm{i} 2.215$

\begin{abstract}
Abstrak
1000 hari pertama kehidupan merupakan suatu periode di dalam proses pertumbuhan dan perkembangan yang dimulai sejak konsepsi sampai anak berusia 2 tahun. Tujuan penelitian ini adalah untuk mengetahui pengaruh edukasi media lembar balik (Flipchart) dalam pemenuhan gizi 1000 hari pertama kehidupan terhadap pengetahuan dan sikap ibu hamil. Desain penelitian quasi eksperimen dengan rancangan pre-post with control group. Penelitian dilakukan 6 Maret - 10 April tahun 2019 di wilayah kerja puskesmas Kota Bengkulu Populasi penelitian ini adalah seluruh ibu hamil yang ada di puskesmas Sawah Lebar dan Jembatan Kecil. Sampel yang digunakan adalah ibu hamil trimester II. Semua sampel diberikan kuesioner pre dan post, kemudian diberikan edukasi pemenuhan gizi 1000 hari pertama kehidupan. Hasil penelitian ini didapatkan ada pengaruh signifikan antara edukasi gizi dengan pengetahuan $(p=0,000)$ dan sikap $(p=0,001)$ sehingga dapat disimpulkan ada pengaruh edukasi gizi media lembar balik (flipchart) dalam pemenuhan gizi 1000 HPK terhadap pengetahuan dan sikap ibu hamil
\end{abstract}

Increased Knowledge and Attitudes of Pregnant Women During Flipchart Education the First 1000 Days of Life

Alamat korespondensi:

${ }^{1}$ Jurusan Gizi, Poltekkes Kemenkes Bengkulu , Indonesia

ISSN 2597-7520

Email: patricknmom@yahoo.co.id

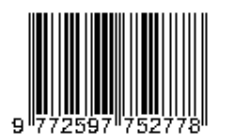

(C) 2020 Poltekkes Kemenkes Ternate 


\section{Pendahuluan}

Gizi merupakan dasar dan pondasi dalam berbagai aspek yang memberi kontribusi pembangunan suatu bangsa yang berhubungan dengan kualitas sumber daya manusia. 1000 HPK atau 1000 hari pertama kehidupan merupakan suatu periode didalam proses pertumbuhan dan perkembangan yang dimulai sejak konsepsi sampai anak berusia 2 tahun (achadi, 2014). Asupan makanan selama 1000 HPK memberi konsekuensi kesehatan untuk masa depan agar anak tumbuh sehat dan cerdas maka gizi sejak anak dini harus terpenuhi dengan tepat dan optimal (Ilmu Fakultas and Unsyiah, 2017)

Berdasarkan penelitian Nasrul, dkk (2018) intervensi menggunakan flipchart dan spanduk bermanfaat meningkatkan perilaku kesehatan 1000 HPK di Sulawesi Tengah dan dilakukan selama 6 bulan dan terdapat peningkatan rerata perilaku pada masing-masing kelompok yang berbeda (Nasrul, 2018).

Masalah gizi yang harus diatasi pada 1000 HPK adalah menurunkan prevalensi balita stunting, anak balita kurus dan juga Berat Bayi Lahir Rendah (BBLR) (Qulub, 2016). Anak-anak yang mengalami hambatan dalam pertumbuhan disebabkan kurangnya asupan makanan, penyakit infeksi yang berulang, serta mengurangi nafsu makan, sehingga meningkatknya kekurangan gizi pada anak. Keadaan itu semakin mempersulit untuk mengatasi gangguan pertumbuhan yang akhirnya terjadi stunted/stunting (Mubasyiroh \& Aya, 2018)

Edukasi gizi merupakan suatu bidang pengetahuan yang memungkinkan seseorang memilih dan mempertahankan pola makan berdasarkan prinsip-prinsip ilmu gizi (Soegeng Santoso, 2008). Edukasi gizi dilakukan dalam lingkup makro dan mikro. Makro yaitu masyarakat luas, sedangkan mikro adalah keluarga atau kelompok anggota masyarakat. Pendekatan juga dapat dibagi atas pendekatan individu dan pendekatan kelompok (Destiyani, 2015)

Dalam penelitian ini menggunakan konsep isi piringku yaitu (1) Memantau berat badan setiap bulan, (2) Konsumsi makanan beranekaragam, (3) Cuci tangan pakai sabun dengan air mengalir, (4) Aktifitas Fisik (Kementerian Kesehatan RI, 2017).

Berdasarkan data yang terjadi serta beberapa hasil penelitian di atas maka penyusun tertarik untuk meneliti pengaruh edukasi media lembar balik (flipchart) dalam Pemenuhan Gizi 1000 Hari Pertama Kehidupan terhadap Pengetahuan dan Sikap Ibu Hamil di Wilayah Kerja Puskesmas Kota Bengkulu.
Penelitian ini menggunakan desain penelitian Pre-post with Control Group Design dengan rancangan penelitian eksperimen semu (quasy experiment). Dilaksanakan pada bulan Maret - April Tahun 2019, edukasi yang diberikan pada masing-masing kelompok yaitu kelompok intervensi menggunakan media flipchart dengan dilakukan edukasi sedangkan kelompok control menggunakan media leaflet tanpa diberikan edukasi. Populasi dalam penelitian ini adalah seluruh ibu hamil yang ada di Wilayah Kerja Puskesmas Sawah Lebar sebanyak 34 orang dan Puskesmas Jembatan Kecil 35 orang. Sampel dalam penelitian ini sebanyak 28 orang pada masing-masing kelompok (28 kelompok intervensi dan 28 kelompok kontrol). Pada kelompok intervensi diberikan edukasi selama 1 bulan dilakukan selama 1x seminggu dan kelompok control hanya diberikan media leaflet tanpa edukas selama 1 bulan dilakukan $2 \mathrm{x}$ semingguTeknik pengambilan sampel yaitu random sampling. Adapun kriteria inklusi adalah ibu hamil trimester II di wilayah kerja puskesmas sawah lebar dan jembatan kecil sedangkan kriteria eksklusi yaitu ibu hamil yang tidak memenuhi kriteria inklusi misalnya ibu hamil trimester 1 dan trimester III.

Variabel yang diteliti adalah variable bebas yaitu edukasi gizi 1000 HPK sedangkan variable terikat pengetahuan dan sikap ibu hamil. Tingkat pengetahuan dan sikap diukur dengan menggunakan kuesioner yang digunakan bersifat pertanyaan terbuka dengan jumlah pengetahuan 20 soal dan sikap 20 pernyataan dengan perhitungan skor jika pernyataan negative maka nilai yang di peroleh yaitu $\quad(\mathrm{SS}=1, \quad \mathrm{~S}=2, \quad \mathrm{TS}=3, \quad \mathrm{STS}=4)$ sedangkan jika pernyataan positif maka nilai yang diperoleh $(\mathrm{SS}=4, \mathrm{~S}=3, \mathrm{TS}=2, \mathrm{STS}=1)$ dengan melakukan edukasi gizi menggunakan media flipchart dan leaflet. Analisis statistic menggunakan uji mann whitney dan uji wilcoxon.

\section{Hasil dan Pembahasan}

Karakteristik responden yaitu usia pada ibu rata-rata 17-40 tahun, hamil anak ke 1-3, pendidikan terakhir rata-rata SMA dan pekerjaan ibu kebanyakan Ibu Rumah Tangga (IRT). Jumlah responden yang diteliti pada penelitian ini sebanyak 54 orang yaitu 28 orang kelompok intervensi dan 28 orang kelompok control.

\section{Metode}


Tabel 1. Rata-rata Pengetahuan dan Sikap Pada Ibu Hamil

\begin{tabular}{|c|c|c|c|}
\hline \multirow[t]{2}{*}{ Variabel } & \multicolumn{3}{|c|}{ Kelompok intervensi } \\
\hline & Mean \pm SD & Min & Max \\
\hline \multicolumn{4}{|l|}{ Pengetahuan } \\
\hline Sebelum & $61,79 \pm 14,35$ & 20 & 80 \\
\hline Sesudah & $81,43 \pm 4,05$ & 70 & 90 \\
\hline \multicolumn{4}{|l|}{ Sikap } \\
\hline Sebelum & $61,93 \pm 2,34$ & 53 & 64 \\
\hline Sesudah & $64,57 \pm 2,45$ & 61 & 72 \\
\hline \multicolumn{4}{|c|}{$\begin{array}{l}\text { Berdasarkan tabel } 1 \text { diketahui bahwa pada } \\
\text { variabel pengetahuan, peningkatan nilai rata-rata } \\
\text { pada kelompok intervensi dengan rata-rata } 61,79 \pm \\
14,35 \text { menjadi } 81,43 \pm 4,05 \text {. Pada variabel sikap, } \\
\text { peningkatan nilai rata-rata pada kelompok } \\
\text { intervensi dengan rata-rata } 61,93 \pm 2,34 \text { menjadi } \\
64,57 \pm 2,45 \text {. }\end{array}$} \\
\hline
\end{tabular}

Tabel 2. Rata-rata Pengetahuan dan Sikap Pada Ibu Hamil

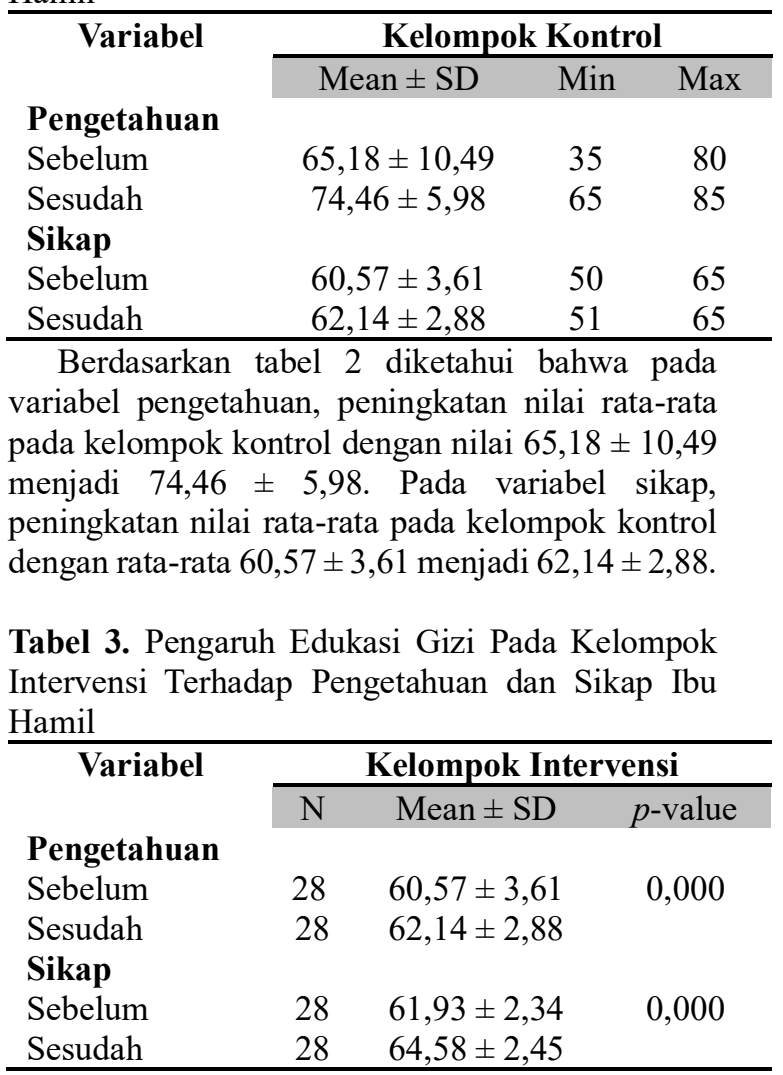

Berdasarkan tabel 5 dapat disimpulkan kelompok intervensi dengan hasil uji statistic wilcoxon $p$-value $0,000(p<0,05)$ menunjukkan ada perbedaan pengetahuan dan sikap sebelum dan sesudah dilakukan edukasi gizi.

Tabel 4. Pengaruh Edukasi Gizi Pada Kelompok Kontrol Terhadap Pengetahuan dan Sikap Ibu
Hamil

\begin{tabular}{lccc}
\hline \multicolumn{1}{c}{ Variabel } & \multicolumn{3}{c}{ Kelompok Kontrol } \\
\cline { 2 - 4 } Pengetahuan & $\mathrm{N}$ & Mean \pm SD & $p$-value \\
Sebelum & 28 & $65,79 \pm 10,4$ & 0,000 \\
Sesudah & 28 & $74,46 \pm 5,98$ & \\
Sikap & & & \\
Sebelum & 28 & $60,57 \pm 3,61$ & 0,000 \\
Sesudah & 28 & $62,14 \pm 2,88$ & \\
\hline
\end{tabular}

Berdasarkan tabel 4 dapat disimpulkan pada kelompok kontrol dengan hasil uji statistic wilcoxon $p$-value $0,000(p<0,05)$ menunjukkan ada perbedaan pengetahuan dan sikap sebelum dan sesudah dilakukan edukasi gizi.

Tabel 5. Efektifitas Media yang digunakan terhadap Pengetahuan dan Sikap Ibu Hamil

\begin{tabular}{lccc}
\hline \multicolumn{1}{c}{ Variabel } & \multicolumn{3}{c}{ Kelompok } \\
\cline { 2 - 4 } & $\mathrm{n}$ & Mean & $p$-value \\
Pengetahuan & & & \\
Intervensi & 28 & 33,39 & 0,006 \\
Kontrol & 28 & 22,61 & \\
Sikap & & & \\
Intervensi & 28 & 31,00 & 0,241 \\
Kontrol & 28 & 26,00 & \\
\hline
\end{tabular}

Berdasarkan tabel 5 variabel pengetahuan, pada kelompok intervensi rata-rata 33,39 dan kelompok kontrol rata-rata 22,61 dengan hasil uji mann whitney $p$-value $0,006 \quad(p<0,05)$ menunjukkan terdapat perbedaan yang signifikan antara kelompok intervensi dan kelompok kontrol dan media yang paling berpengaruh terdapat pada kelompok intervensi yaitu menggunakan media flipchart sedangkan variabel sikap pada kelompok intervensi rata-rata 31,00 dan kelompok kontrol rata-rata 26,00 dengan hasil uji mann whitney $p$ value $0,242(p>0,05)$ menunjukkan tidak ada perbedaan yang signifikan antara kelompok intervensi dan kelompok kontrol dan media yang paling berpengaruh terdapat pada kelompok intervensi yaitu menggunakan media flipchart.

\section{Pengaruh Edukasi Gizi Menggunakan Media Terhadap Pengetahuan dan Sikap Ibu Hamil}

Pada uji statistic uji wilcoxon yang dilakukan didapatkan $\rho$ value $0,000(\rho<0,05)$ berarti ada pengaruh edukasi gizi menggunakan media flipchart terhadap pengetahuan dan sikap pada ibu hamil keberhasilan edukasi yang dilakukan dapat dilihat dari hasil nilai pengetahuan dan sikap pada kelompok intervensi menggunakan media flipchart.

Penelitian ini sejalan dengan penelitian (Nasrul, 2018) yaitu adanya pengaruh terhadap peningkatan rerata perilaku intervensi flipchart dengan intervensi spanduk dengan hasil uji statistic 
yang didapatkan $\rho=0,002(<0,05)$. Penelitian ini menunjukkan bahwa dengan semakin tingginya tingkat pendidikan seseorang makan akan dapat meningkatkan perilaku ibu mengenai pengetahuan dan bisa merubah sikap pada ibu tersebut atau bisa diaplikasikan pada kehidupan sehari-hari.

Menurut penelitian (Nasrul, 2018) penggunaan flipchart dan spanduk sebagai alat komunikasi merupakan strategi komunikasi untuk menerapkan perilaku positif yang sesuai dengan masalah local, norma dan aturan yang ada. Manfaat flipchart dan spanduk pada program spesifik 1000 HPK merupakan bukti dan proses berbasis penelitian yang menggunakan media komunikasi untuk mempromosikan perilaku yang mengarah pada peningkatan hasil kesehatan.

Menurut penelitian (Umar, 2016) yang berjudul pengaruh pendidikan gizi terhadap penegathuan ibu balita usia 24-48 bulan diwilayah puskesmas Tanete kabupaten Bulukumba dan didapatkan hasil uji Wilcoxon dengan rerata pengetahuan ibu balita dalam pretest adalah 37,69 $\pm 3,302$ dan post test $44,12 \pm 3,117$, nilai media pretest 38,00 dan nilai minimum - maksimum 30 44. Hasil uji Wilcoxon menunjukkan bahwa melalui intervensi spesifik pendidikan terhadap pengetahuan ibu balita berpengaruh secara signifikan dengan nilai $\rho=0,000(\rho<0,05)$

Hasil penelitian (Melly \& Magdalena, 2018), menyatakan adanya peningkatan pengetahuan dan sikap pada responden setelah melalui penyuluhan dengan metode ceramah sejalan dengan Penelitian Pasaribu (2005) menyatakan bahwa nilai rata-rata pengetahuan meningkat setelah dilakukan metode ceramah Menurut Notoatmodjo (2012), semakin banyak informasi dapat pengetahuan menimbulkan kesadaran yang akhirnya seseorang akan bersikap dan berprilaku sesuai dengan pengetahuan yang dimiliki dan Tanya jawab.

Menurut Wawan (2010), tahu yaitu mengingat suatu materi yang telah dipelajari sebelumnya termasuk mengingat kembali atau recall sesuatu yang spesifik dan seluruh bahan yang dipelajari atau rangsangan yang telah diterima, oleh karena itu tahu ini merupakan tingkat pengetahuan yang paling rendah (Pratama et al., 2017)

Menurut Farinta (2018) hasil uji statistic paired sample $t$ test pada $\alpha=0,05$ dengan membandingkan nilai pre test dan post test pengetahuan dan sikap dari media yang digunakan diperoleh nilai $\rho$ value $0,000(\rho<0,05)$ maka $\mathrm{H}_{0}$ ditolak artinya ada perbedaan atau peningkatan antara pengetahuan ibu tengan MP ASI sebelum dan sesudah pendidikan gizi menggunakan media leaflet (Generasi \& Lebih, n.d.). Penelitian yang hampir serupa juga diungkapkan oleh Muthmainah (2015) tentang pengaruh penyuluhan dengan media audio visual dan leaflet terhadap pengetahuan ibu tentang pemberian makanan pendamping ASI dengan hasil penelitian bahwa terdapat pengaruh penyuluhan dengan media audio visual $(0,000$ $<0,05)$ dan media leaflet $(0,001<0,05)$ (Melly \& Magdalena, 2018)

\section{Faktor-faktor yang bisa meningkatkan pengetahuan dan sikap}

Hasil uji statistik dengan menggunakan Mann Whitney didapatkan hasil pengetahuan $\rho$ value $0,000(\rho<0,05)$ sedangkap hasil sikap $\rho$ value $0,001 \quad(\rho<0,05)$ jadi dapat disimpulkan bahwa adanya perbedaan antara pengetahuan sebelum dan sesudah dilakukan edukasi gizi antara media leaflet dan flipchart.

Adapun beberapa factor yang bisa meningkatkan pengetahuan yaitu (1) Pendidikan karena semakin tinggi pendidikan maka semakin luas pengetahuan yang diketahui, (2) Informasi atau media massa yaitu menurut Azwar (2003) pengetahuan dapat dipengaruhi oleh adanya informasi atau media massa sebagai sarana komunikasi yang dibaca atau diliha, baik dari media cetak maupun media elektronik seperti televise, radio, surat kabar, majalah dan lainnya, (3)

Social, budaya dan ekonomi menurut Nursalam (2001) semakin luas pengetahuan social dan budaya bisa meningkatkan pengetahuan dan sikap seseorang serta status ekonomi yang tersedia dan mencukupi akan mempengaruhi pengetahuan seseorang, (4) Lingkungan karena dilingkungan terjadinya interaksi timbal balik antara masyarakat dan hal itu bisa meningkatkan pengetahuan seseorang, (5) Pengalaman merupakan suatu cara untuk memperoleh kebenaran pengetahuan dengan cara mengulang kembali pengetahuan yang diperoleh dalam memecahkan masalah sehingga bisa dipergunakan untuk meningkatkan pengetahuan di masa depan, (6) Usia karena semakin muda usia maka pola pikirnya masih kurang dan bila seseorang sudah memasuki usia yang lebih tua maka pola pikirnya bisa dapat lebih baik dan lebih bijaksana (Notoadmojdo, 2007)

Media edukasi leaflet dengan flipchart memiliki kelebihan dan kekurangannya masingmasing. Kelebihan media leaflet mudah untuk dibawa kemana-mana sedangkan media flipchart materi yang disampaikan lebih terperinci dan jelas tentang mengulas pesan yang akan disampaikan saat edukasi (Perdana et al., 2017)

Responden yang diteliti kebanyakan belum pernah mengetahui apa itu arti gizi 1000 hari pertama kehidupan (1000 HPK), ada sebagian responden yang sudah mengetahui apa itu 1000 
HPK tetapi tidak mengetahui lebih dalam atau lebih jelas lagi tentang 1000 HPK. Gizi 1000 HPK kepada ibu hamil merupakan awal dari pertumbuhan anak hingga berumur 2 tahun atau pada saat masa-masa anak tumbuh secara pesat.

Menurut penelitian Rosani (2017) didapatkan hasil uji perbedaan intensi dengan menggunakan Mann Whitney test sebelum dan sesudah mendapatkan edukasi berbasis keluarga pada kelompok intervensi dan edukasi melalui pelayanan antenatal care (ANC) di Puskesmas pada kelompok control dan kelompok intervensi. Nilai selisih rata-rata intensi pada kelompok control sebelum dan sesudah dilakukan intervensi dengan nilai $\mathrm{z}=-4,91$ dan $\rho$ value $=0,000$. Nilai $\rho$ value $=$ 0,00 lebih besar dari alpha 0,05 artinya ada perbedaan bermakna pre test dan post test pada kelompok intervensi yang mendapatkan edukasi berbasis keluarga untuk optimalisasi nutrisi pada 1000 HPK (Naim et al., 2017)

Frekuensi edukasi gizi juga berpengaruh dalam peningkatan pengetahuan dan sikap yang diberikan saat edukasi gizi. Frekuensi edukasi gizi yang diberikan dalam penelitian ini yaitu $4 \mathrm{x}$ dalam sebulan atau 1x seminggu. Berdasarkan peneliyoan Mona (2012) frekuensi konsultasi gizi terbanyak terbanyak 2-4x dalam sebulan dengan mengikuti kepatuhan gizi yang diberikan dengan ketegori cukup patuh $(61,8 \%)$ (Sartika, 2012)

Dalam hal ini baik media flipchart maupun media leaflet dapat meningkatkan pengetahuan ibu, hal ini ditunjukkan dengan hasil uji mann whitney dan uji Wilcoxon mengalami peningkatan . namun tidak dengan sikap yang ditunjukkan dengan hasil uji statistic yang kurang dari taraf signifikan antara media yang dilakukan antara media yang digunakan antara flipchart dan leaflet.

Media leaflet merupakan alat bantu praktis dan dapat membantu responden memahami jenis, ukuran dan berat bahan makanan serta mudah untuk di bawa. Sedangkan media flipchart adalah media yang berisikan gambar peragaan dan meteri yang berisikan gagasan ke pokok persoalannya. Responden lebih mengerti jikan menggunakan flipchart karena lebih jelas dan lebih terinci.

\section{Penutup}

Berdasarkan hasil penelitian dan pembahasan tentang pengaruh edukasi media lembar balik (flipchart) dalam pemenuhan gizi 1000 HPK terhadap pengetahuan dan sikap ibu hamil di wilayah kerja puskesmas kota Bengkulu tahun 2019 maka didapatkan kesimpulan yaitu Hasil uji beda nilai pengetahuan dan sikap sebelum dan sesudah dengan uji Mann Whitney menunjukkan nilai pengetahuan $\rho$ $=0,000$ dan nilai sikap $\rho=0,001$ berarti ada perbedaan yang signifikan diantara kedua kelompok perlakuan Media yang paling berpengaruh untuk digunakan yaitu media flipchart

Penelitian ini dapat dikembangkan lagi dengan menambah variabel dan diharapkan penelitian ini dapat digunakan untuk pengembangan kurikulum mengenai gizi 1000 hari pertama kehidupan bagi ibuibu hamil atau wanita usia subur.

\section{Daftar Pustaka}

Achadi, E. (2014). Periode Kritis 1000 HPK dan Dampak Jangka Panjang Terhadap Kesehatan dan Fisiknya. FKM Universitas Indonesia, November. https://doi.org/10.1029/2010ja015955

Almatsier, Sunita. (2011). Gizi Seimbang Dalam Daur Kehidupan. Pt Gramedia Pustaka Utama: Jakarta.

Arisman. (2007). Gizi Dalam Daur Kehidupan. Jakarta : Penerbit Buku Kedokteran

Destiyani, C. (2015). Pengaruh edukasi gizi menggunakan media.

Generasi, U., \& Lebih, Y. (n.d.). Pendidikan kesehatan ibu hamil "1000 hari pertama $k$ ehidupan untuk generasi yang lebih baik. "713.

Ilmu, B., Fakultas, G., \& Unsyiah, K. (2017). Nutrisi pada 1000 Hari Pertama Kehidupan. Jurnal Kedokteran Syiah Kuala, 17(3), 179183.

Kementerian Kesehatan RI. (2017). Leaflet Isi Piringku (pp. 1-16). www.kesmas.kemkes.go.id

Kementrian Kesehatan Ri (2018) 'Hasil Utama Laporan Riskesdas 2018', Jakarta: Badan Penelitian Dan Pengembangan Kesehatan Departemen Kesehatan Republik Indonesia. Doi: 1 Desember 2013.

Melly, \& Magdalena. (2018). PENGARUH PENYULUHAN METODE CERAMAH DAN AUDIO-VISUAL Poltekkes Kemenkes Riau, Jl . Melur No . 103 , Pekanbaru, 28122 Gerakan Hari Pertama terjadi di Indonesia harus segera diatasi mengingat dampaknya yang sangat besar bagi kelangsungan hidup suatu bangsa. Jurnal Mahakam Midwifery, 2(4), 255-266.

Mubasyiroh, L., \& Aya, Z. C. (2018). HUBUNGAN PERILAKU IBU DALAM PEMENUHAN GIZI PADA PERIOD DENGAN STATUS GIZI BALITA DI DESA SITANGGAL KECAMATAN LARANGAN KABUPATEN BREBES TAHUN 2018. Ilmu 
Kesehatan Bakti Husada, 09(01), 18-27.

Naim, R., Juniarti, N., \& Yamin, A. (2017). Pengaruh Edukasi Berbasis Keluarga terhadap Intensi Ibu Hamil untuk Optimalisasi Nutrisi pada 1000 Hari Pertama Kehidupan. Jurnal Keperawatan Padjadjaran, $5(2)$. https://doi.org/10.24198/jkp.v5i2.475

Nasrul, D. (2018). Manfaat Media Flipchart dan Spanduk dalam Perilaku Kesehatan 1000 HPK di Sulawesi Tengah The Benefits of Flipchart Media and Banner Toward Health Behavior the First 1000 Days of Life in Central Sulawesi. Jurnal MIKMI, 14(1), 5260.

https://doi.org/10.30597/mkmi.v14i1.1870

Notoatmodjo, Soekijdjo. 2012. Pendidikan Dan Perilaku Kesehatan. (Jakarta: Rineka Cipta, 2003).

Perdana, F., Madanijah, S., \& Ekayanti, I. (2017). Pengembangan media edukasi gizi berbasis android dan website serta pengaruhnya terhadap perilaku tentang gizi seimbang siswa sekolah dasar. Jurnal Gizi Dan Pangan, 12(3), 169-178. https://doi.org/10.25182/jgp.2017.12.3.169178

Pratama, A. P., Riyanti, E., Cahyo, K., Masyarakat, F. K., \& Diponegoro, U. (2017). Pengaruh edukasi gerakan $1000 \mathrm{hpk}$ terhadap perbaikan pola makan ibu hamil risti di wilayah kerja puskesmas kedungmundu kota semarang. Jurnal Kesehatan Masyarakat Nasional, 5(5), 926-938.

Profil Kesehatan Provinsi Bengkulu' (2017), 91, Pp. 399-404.

Qulub, S. T. (2016). 1000 HARI PERTAMA KEHIDUPAN PERSPEKTIF HUKUM ISLAM. 2(2).

Sartika, R. A. D. (2012). Penerapan Komunikasi, Informasi , dan Edukasi Gizi terhadap Perilaku Sarapan Siswa Sekolah Dasar Implementation of Communication , Information, and Education on Nutrition towards Primary School Students Breakfast Behavior. Jurnal Kesehatan Masyarakat Nasional, 7 No 2, 76-82.

Soegeng Santoso. 2008. Kesehatan dan Gizi. Jakarta: Universitas Terbuka.

Umar, S. (2016). Pengaruh pendidikan gizi terhadap pengetahuan ibu balita usia 24 - 48 bulan di wilayah puskesmas tanete kabupaten bulukumba. 